\title{
ADSORPSI ION MN(II) PADA ZEOLIT DARI ABU DASAR BATUBARA TERMODIFIKASI DITIZON
}

\section{AN ADSORPTION OF Mn(II) FROM ZEOLITE COAL DITIZON MODIFIED}

\author{
Riandy Putra $^{1}$, Khamidinal ${ }^{1}$, Didik Krisdiyanto ${ }^{1 *}$, dan Irwan Nugraha ${ }^{1}$ \\ ${ }^{1}$ Program Studi Kimia, Fakultas Sains dan Teknologi, UIN Sunan Kalijaga Yogyakarta \\ Jl. Marsda Adisucipto No. 1 Yogyakarta 55281 \\ *Email : didik_kris@yahoo.com
}

Diterima : 10 Juli 2015, Revisi : 31 Juli 2015, Disetujui : 06 Agustus 2015

\begin{abstract}
ABSTRAK
Telah dilakukan penelitian adsorpsi Mn (II) pada zeolit yang disintesis dari abu dasar batubara dan dimodifikasi dengan ditizon. Dipelajari parameter adsorbsi meliputi pengaruh $\mathrm{pH}$, variasi waktu, konsentrasi awal dan temperatur. Zeolit hasil sintesis dan zeolit ditizon dikarakterisasi mengunakan XRF, XRD, FT-IR dan SAA. Hasil karakterisasi menunjukkan bahwa zeolit yang terbentuk merupakan campuran zeolit $\mathrm{Y}$, zeolit X, Na-zeolit serta kristal sodalit. Adanya ditizon dalam zeolit ditizon dapat diidentifikasi dari serapan FTIR pada bilangan gelombang 1496,76 dan 2461,17 $\mathrm{cm}^{-1}$ yang merupakan serapan gugus $\mathrm{NH}$ dan $-\mathrm{SH}$ dari ditizon. Hasil analisa luas permukaan menunjukkan bahwa adanya ditizon pada zeolit ditizon menurunkan luas permukaan spesifik dari $160,262 \mathrm{~m}^{2} / \mathrm{g}$ menjadi $69,609 \mathrm{~m}^{2} / \mathrm{g}$. Adsorbsi $\mathrm{Mn}(\mathrm{II})$ pada berbagai $\mathrm{pH}$ menunjukkan bahwa zeolit mengadsopsi optimum pada pH 6 sedangkan zeolit ditizon pada $\mathrm{pH}$ 8. Kinetika adsorpsi menunjukkan zeolit dan zeolit ditizon mengikuti persamaan orde dua semu dengan konstanta laju $-0,014$ g/mg.min ${ }^{-1}$ dan 0,0204 g/mg.min ${ }^{-1}$. Kesetimbangan adsorpsi menunjukkan kedua adsorben mengikuti persamaan langmuir dengan kapasitas adsorpsi 14,493 mg/g dan 15,873 mg/g. Kajian termodinamika menunjukkan bahwa adsorbsi berlangsung spontan pada temperatur relatif rendah.
\end{abstract}

Kata kunci: Abu dasar, zeolit, hidrotermal, ditizon, adsorpsi

\section{ABSTRACT}

Adsorption characteristic of Mn(II) on zeolite synthesized from bottom ash with alkaline hydrothermal conditions loaded with dithizone have been examined. The parameters studied includes effect of $\mathrm{pH}$, contact time, initial concentrations and temperature of $M n(I I)$ by batch experiments. The raw and modified samples were characterized by XRF, XRD, FT-IR and SAA. The results of XRD and FTIR showed that hydrothermal product consists of a mixture of zeolite (zeolite $Y$, zeolite $\mathrm{Na}-\mathrm{P}$ and zeolite $\mathrm{X}$ ) and sodalite crystals. Hydrothermal product showed specific IR absorption zeolite at wavenumber $300-1250 \mathrm{~cm}^{-1}$ and zeolite modified dithizone showed absorption $\mathrm{NH}$ and -SH at wavenumber 1496,76 and 2461,17 $\mathrm{cm}^{-1}$. The results SAA showed that with addition dithizone lowering the specific surface area of zeolite from 160,262 $\mathrm{m}^{2} / \mathrm{g}$ to $69,609 \mathrm{~m}^{2} / \mathrm{g}$. Results of study show that adsorption of Mn(II) reaches its maximum values at $\mathrm{pH} 6$ for zeolite and $\mathrm{pH} 8$ for zeolite modified dithizone, respectively. The adsorption kinetics based on the pseudo-secondorder rate equation with adsorption rate constants for zeolite synthesis $-0,014 \mathrm{~g} / \mathrm{mg}_{\mathrm{min}} \mathrm{mind}^{-1}$ for the zeolite modified dithizone $0,0204 \mathrm{~g} / \mathrm{mg} \mathrm{min}^{-1}$. Based on the Langmuir equation, the maximum adsorption capacity $\left(q_{\max }\right)$ synthetic zeolite of $14,493 \mathrm{mg} / \mathrm{g}$ and zeolite modified dhitizone $15,873 \mathrm{mg} / \mathrm{g}$. Termodynamic parameter indicated thatadsorption using two adsorbents takes place spontaneously at a lower temperature.

Keywords: Bottom ash, zeolite, hydrothermal, dithizone, adsorption

\section{PENDAHULUAN}

Abu batubara merupakan materi sisa yang ada setelah semua materi yang dapat bakar (flameable) pada batubara telah habis terbakar ${ }^{(1)}$. Abu dasar memiliki kandungan Si dan Al yang cukup banyak 
sehingga abu dasar dapat digunakan sebagai bahan dasar pembuatan zeolit.

Zeolit merupakan suatu mineral aluminosilikat dengan struktur kristal yang terdiri dari tiga komponen yaitu kation yang dapat dipertukarkan, kerangka aluminosilikat dan air. Metode peleburan abu dasar diikuti proses hidrotermal menunjukkan bahwa terbentuknya zeolit A menghasilkan kristalinitas dan kemurnian lebih tinggi dibandingkan hidrotermal langsung abu dasar dengan masih adanya karbon $^{(2-4)}$. Hal tersebut juga berlaku ketika untuk sintesis zeolit tertentu dari abu layang 5 .

Untuk meningkatkan kemampuan zeolit sebagai adsorben maka perlu dilakukan modifikasi.Beberapa metode yang sering digunakan yaitu memodifikasi sifat permukaan zeolit dan pencucian menggunakan asam ${ }^{(6)}$. Pencucian menggunakan asam akan menghilangkan pengotor yang terdapat pada porizeolit sehingga permukaan pori zeolit akan menjadi lebih luas $^{(7)}$. Modifikasi lain adalah dengan menggunakan berbagai macam ligan untuk meningkatkan kapasitas retensi dan selektivitasnya. Ditizon (1,5-difeniltiokarbazon) merupakan ligan yang sensitif dan spesifik karena mengandung banyak atom donor $\mathrm{N}$, gugus -NH serta -SH yang sangat spesifik untuk berperan sebagai donor pasangan elektron membentuk khelat dengan adsorben dalam mengadsorpsi ion logam transisi termasuk $\mathrm{Pb}, \mathrm{Cd}$ dan $\mathrm{Hg}^{(8)}$. Penelitian mengenai zeolit termodifikasi ditizon telah banyak dilaporkan salah satunya penelitian tentang karakterisasi adsorpsi ion $\mathrm{Pb}$ (II) dan $\mathrm{Cd}(\mathrm{II})$ menggunakan zeolit alam termodifikasi ditizon. Dalam penelitian tersebut, kemampuan zeolit alam termodifkasi ditizon dalam menjerap dua logam lebih baik daripada zeolit alam tidak dimodifikasi ${ }^{(9)}$. Dapat pula menggunakan alumina yang dikembangkan dengan adsorpsi permukaan ditizon untuk menjerap ion logam $\mathrm{Pb}$ dan ion logam lain maupun adsorpsi ion logam $\mathrm{Pb}$ menggunakan agen pengkelat ditizon juga dan dengan adsoben amberlite XAD-16 ${ }^{(10-}$ 11). Adsorpsi menggunakan silika gel yang dimodifikasi dengan ditizon untuk ion logam $\mathrm{Cu}$ maupun nanopartikel Klinoptilolit oleh surfaktan kation dan ditizon untuk menghilangkan larutan $\mathrm{Pb}$ (II) dan menyatakan bahwa nanopartikel yang termodifikasi surfaktan kation dan ditizon dapat meningkatkan luas permukaan secara efektif serta secara signifikan meningkatkan penghilangan $\mathrm{Pb}(\mathrm{II})^{(12-13)}$.

Dalam penelitian ini, zeolit hasil sintesis abu dasar batubara dimodifikasi dengan ditizon kemudian digunakan untuk mengadsorpsi polutan $\mathrm{Mn}$ (II).Ion $\mathrm{Mn}$ (II) banyak terdapat di perairan baik secara alami maupun akibat adanya kontaminan yang berasal dari industri seperti pengolahan besi dan baja. Apabila konsentrasi mangan didalam tubuh kita cukup tinggi dapat menyebabkan gangguan saluran pernapasan dan kerusakan syaraf. Adsorpsi ion $\mathrm{Mn}$ (II) oleh zeolit hasil sintesis dari abu dasar batubara yang termodifikasi ditizon yang dipelajari dalam penelitian ini meliputi kinetika adsorpsi, kesetimbangan dan termodinamika adsorpsi.

\section{BAHAN DAN METODA}

\section{Bahan}

Bahan yang digunakan dalam penelitian antara lain abu dasar batubara, ditizon, $\mathrm{HCl}$ pekat, akuades, pelet $\mathrm{NaOH}$, natrium silikat, etanol $96 \%$, dietil eter dan mangan (II) sulfat $\left(\mathrm{MnSO}_{4} \cdot \mathrm{H}_{2} \mathrm{O}, \mathrm{Mr}=\right.$ $168,91 \mathrm{~g} / \mathrm{mol})$.

\footnotetext{
Alat

Alat-alat penelitian yang digunakan adalah seperangkat alat gelas kimia, alat refluks, kertas saring whatman 42, kertas
} 
$\mathrm{pH}$, tabung sentrifus, mortar dan lumpang porselen, krus nikel, bejana teflon, pengaduk magnet, ayakan 250 mesh, $\mathrm{pH}$ meter, neraca analitik, hot plate, sentrifus, shaker water batch, shakerincubator, furnace, oven, XRF, (XRD) Shimadzu 6000, (FTIR) Shimadzu Prestige-21, (GSA) Quantachroome NovaWin2 danAAS.

\section{Preparasi Abu Dasar}

Abu dasar batubara yang berasal dari Pabrik spiritus Madukismo Yogyakarta digerus menggunakan lumpang porselen hingga halus kemudian diayak dengan ayakan hingga lolos > $106 \mu \mathrm{m}$. Abu dasar yang telah lolos ayakan kemudian ditimbang sebanyak 10 gram, ditambah dengan $100 \mathrm{~mL} \mathrm{HCl}$ pekat, dan direfluks pada suhu $80{ }^{\circ} \mathrm{C}$ selama 4 jam. Hasil refluks kemudian disaring dan dicuci dengan akuades sampai $\mathrm{pH}$ netral. Padatan yang dihasilkan kemudian dioven pada suhu $160{ }^{\circ} \mathrm{C}$ selama 8 jam. Dilanjutkan dengan 2,5 gram padatan dan 2,5 gram pelet $\mathrm{NaOH}$ digerus menggunakan lumpang porselin sampai halus, dimasukkan dalam krus nikel lalu dilebur pada suhu $550{ }^{\circ} \mathrm{C}$ selama 60 menit. Padatan hasil peleburan didinginkan dan digerus.

\section{Sintesis zeolit}

Abu dasar yang diperoleh dari hasil peleburan dengan $\mathrm{NaOH}$, dimasukkan dalam bejana teflon, ditambahkan dengan $10 \mathrm{~mL}$ natrium silikat dan $15 \mathrm{~mL}$ akuades kemudian diaduk dengan pengaduk magnet selama 24 jam. Hasil tersebut kemudian direaksikan secara hidrotermal pada suhu $100{ }^{\circ} \mathrm{C}$ selama 24 jam. Padatan hasil hidrotermal dipisahkan dengan kertas saring, dinetralkan dengan akuades dan dikeringkan dalam oven pada suhu $100{ }^{\circ} \mathrm{C}$ selama 1 jam. Hasil yang diperoleh berupa zeolit abu dasar batubara yang diperoleh kemudian dikarakterisasi dengan menggunakan XRF, XRD, FTIR, dan GSA.

\section{Modifikasi zeolit dengan ditizon}

Difeniltiokarbazon (ditizon) sebanyak 2,56 gram $(\sim 10,0 \quad \mathrm{mmol})$ dimasukkan ke dalam $500 \mathrm{~mL}$ labu bulat dan dilarutkan sempurna dalam $400 \mathrm{~mL}$ etanol $96 \%$ dengan pemanasan pada 50 ${ }^{\circ} \mathrm{C}$. Larutan kemudian ditambah dengan 10 gram Z-AD dan direaksikan selama 6 jam pada suhu tersebut. Fase zeolit yang telah dimodifikasi disaring dan dicuci menggunakan $50 \mathrm{~mL}$ etanol sebanyak tiga kali ulangan kemudian dicuci dengan 50 $\mathrm{mL}$ dietil eter. Hasil yang dihasilkan kemudian dikeringkan dalam udara terbuka selama semalam ${ }^{(10)}$. Zeolit ditizon yang diperoleh kemudian dikarakterisasi dengan menggunakan XRF, XRD, FTIR, dan GSA.

\section{Adsorpsi Mn(II) dengan variasi pH}

Adsorpsi variasi $\mathrm{pH}$ dikerjakan dengan cara sebanyak $15 \mathrm{~mL}$ larutan $\mathrm{Mn}$ (II) $150 \mathrm{ppm}$ dan diatur $\mathrm{pH}$ larutannya dengan cara menambahkan $\mathrm{HCl}$ atau $\mathrm{NaOH}$ menjadi larutan $\mathrm{Mn}(\mathrm{II})$ dengan $\mathrm{pH}$ 4, 5, 6, 7 dan 8. Masing-masing larutan di masukkan ke dalam erlenmeyer $50 \mathrm{~mL}$ dan ditambahkan sebanyak 0,15 gram zeolit sintesis. Kemudian dilakukan adsorpsi menggunakan shaker water bath dengan kecepatan 125 rpm selama 60 menit. Larutan hasil adsorpsi disaring menggunakan kertas saring. Kemudian, filtrat dianalisis menggunakan AAS untuk mengetahui konsentrasi logam Mn (II). Perlakuan yang sama juga dilakukan pada adsorben zeolit ditizon.

\section{Adsorpsi Mn(II) dengan variasi waktu}

Adsorpsi variasi waktu dikerjakan dengan cara sebanyak $15 \mathrm{~mL}$ larutan Mn(II) $150 \quad$ ppm masing-masing 
dimasukkan ke dalam 5 buah erlenmeyer $50 \mathrm{~mL}$ yang berbeda. Kemudian masingmasing erlenmeyer ditambahkan 0,15 gram zeolit sintesis dan dilakukan adsorpsi menggunakan shaker water bath dengan kecepatan 125 rpm selama 30 menit, 60 menit, 90 menit, 120 menit dan 150 menit. Larutan hasil adsorpsi disaring menggunakan kertas saring. Kemudian, filtrat dianalisis menggunakan AAS untuk mengetahui konsentrasi logam $\mathrm{Mn}(\mathrm{II})$. Perlakuan yang sama juga dilakukan pada adsorben zeolit ditizon.

\section{Adsorpsi Mn(II) dengan variasi konsentrasi awal}

Adsorpsi konsentrasi awal ion logam kerjakan dengan cara larutan standar $\mathrm{Mn}$ (II) dibuat variasi konsentrasi awal larutan Mn(II) 20 ppm, 40 ppm, 60 ppm, 100 ppm, 150 ppm dan 200 ppm. Masingmasing dipipet sebanyak $4 \mathrm{~mL}, 8 \mathrm{~mL}, 12$ $\mathrm{mL}, 20 \mathrm{~mL}, 30 \mathrm{~mL}$ dan $40 \mathrm{~mL}$ larutan standar Mn(II) 500 ppm ke dalam labu ukur $100 \mathrm{~mL}$. Larutan diencerkan menggunakan akuades dan dikocok sampai homogen. Selanjutnya diambil sebanyak $15 \mathrm{~mL}$ larutan $\mathrm{Mn}$ (II) dari berbagai variasi konsentrasi ke dalam erlenmeyer. Kemudian dilakukan adsorpsi menggunakan shaker water bath pada kecepatan 125 rpm selama 24 jam dengan menambahkan 0,15 gram zeolit sintesis. Larutan hasil adsorpsi disaring menggunakan kertas saring. Kemudian, filtrat dianalisis menggunakan AAS untuk mengetahui konsentrasi logam Mn(II). Perlakuan yang sama juga dilakukan pada adsorben zeolit ditizon.

\section{Adsorpsi Mn(II) dengan variasi temperatur}

Adsorpsi variasi temperatur dikerjakan dengan cara sebanyak $15 \mathrm{~mL}$ larutan $\mathrm{Mn}$ (II) $\quad 150 \quad \mathrm{ppm}$ masing-masing dimasukkan ke dalam 5 buah erlenmeyer $50 \mathrm{~mL}$ yang berbeda. Kemudian masing- masing erlenmeyer ditambahkan 0,15 gram zeolit sintesis. Campuran diaduk menggunakan shaker incubator dan dipanaskan pada suhu 30, 40, 50, dan 60 ${ }^{0} \mathrm{C}$ selama 60 menit. Larutan hasil adsorpsi disaring menggunakan kertas saring. Kemudian, filtrat dianalisis menggunakan AAS untuk mengetahui konsentrasi logam Mn(II). Perlakuan yang sama juga dilakukan pada adsorben zeolit ditizon.

\section{HASIL DAN PEMBAHASAN}

\section{Karakterisasi zeolit dan zeolit ditizon}

Hasil analisa senyawa dengan XRF terhadap zeolit hasil sintesis dan zeolit yang termodifikasi ditizon ditunjukkan pada Tabel 1 dan Tabel 2.

Tabel 1. Komposisi senyawa dalam zeolit sintesis

\begin{tabular}{cccc}
\hline Senyawa & $\begin{array}{c}\text { Kadar } \\
(\% \text { berat })\end{array}$ & Senyawa & $\begin{array}{c}\text { Kadar } \\
(\% \text { berat })\end{array}$ \\
\hline $\mathrm{SiO}_{2}$ & 65,79 & $\mathrm{Cr}_{2} \mathrm{O}_{3}$ & 0,22 \\
$\mathrm{Al}_{2} \mathrm{O}_{3}$ & 18,00 & $\mathrm{NiO}$ & 0,06 \\
$\mathrm{TiO}_{2}$ & 7,07 & $\mathrm{CuO}$ & 0,04 \\
$\mathrm{Fe}_{2} \mathrm{O}_{3}$ & 2,80 & $\mathrm{MnO}$ & 0,03 \\
$\mathrm{SO}_{3}$ & 1,12 & $\mathrm{Y}_{2} \mathrm{O}_{3}$ & 0,02 \\
$\mathrm{MgO}$ & 1,09 & $\mathrm{SrO}$ & 0,02 \\
$\mathrm{~K}_{2} \mathrm{O}$ & 0,90 & $\mathrm{ZnO}$ & 0,02 \\
$\mathrm{Cl}$ & 0,83 & $\mathrm{PbO}$ & 0,02 \\
$\mathrm{CaO}$ & 0,66 & $\mathrm{Bi} 2 \mathrm{O}_{3}$ & 0,01 \\
$\mathrm{P}_{2} \mathrm{O}_{5}$ & 0,51 & $\mathrm{Ga}_{2} \mathrm{O} 3$ & 0,01 \\
$\mathrm{La}_{2} \mathrm{O} 3$ & 0,41 & $\mathrm{Nb}_{2} \mathrm{O} 5$ & 0,01 \\
$\mathrm{ZrO}_{2}$ & 0,32 & & \\
\hline
\end{tabular}

Berdasarkan Tabel 1 dan Tabel 2 memperlihatkan bahwa secara garis besar zeolit setelah dimodifikasi ditizon tidak merubah kadar komponen-komponen $\mathrm{SiO}_{2}$ dan $\mathrm{Al}_{2} \mathrm{O}_{3}$ secara signifikan atau tidak berbeda jauh dengan sebelum dimodifikasi. 
Namun, senyawa $\mathrm{SO}_{3}$ pada zeolit termodifikasi yang memiliki unsur sulfur mengalami peningkatan sebesar $6,47 \%$ dengan sebelum ditambahkan ditizon. Hal ini menunjukkan bahwa ditizon telah berhasil dimodifikasi pada zeolit. Hasil penelitian ini telah terbentuk zeolit jenis zeolit Y, sodalit, zeolit Na-P dan zeolit X. Pola difraksi dari zeolit sintesis dan zeolit termodifikasi ditizon disajikan pada Gambar 1.

Tabel 2. Komposisi senyawa dalam zeolit termodikasi ditizon

\begin{tabular}{cccc}
\hline Senyawa & $\begin{array}{c}\text { Kadar } \\
\text { (\% berat) }\end{array}$ & Senyawa & $\begin{array}{c}\text { Kadar } \\
\text { (\% berat })\end{array}$ \\
\hline $\mathrm{SiO}_{2}$ & 64 & $\mathrm{ZrO}_{2}$ & 0,24 \\
$\mathrm{Al}_{2} \mathrm{O}_{3}$ & 19,01 & $\mathrm{La}_{2} \mathrm{O}$ & 0,18 \\
$\mathrm{SO}_{3}$ & 6,47 & $\mathrm{Cr}_{2} \mathrm{O}_{3}$ & 0,11 \\
$\mathrm{TiO}_{2}$ & 5,66 & $\mathrm{NiO}$ & 0,05 \\
$\mathrm{Fe}_{2} \mathrm{O}_{3}$ & 2,35 & $\mathrm{CuO}$ & 0,02 \\
$\mathrm{~K}_{2} \mathrm{O}$ & 0,63 & $\mathrm{SrO}$ & 0,02 \\
$\mathrm{Cl}$ & 0,52 & $\mathrm{ZnO}$ & 0,02 \\
$\mathrm{CaO}$ & 0,34 & $\mathrm{Y} \mathrm{O}_{3}$ & 0,01 \\
$\mathrm{P}_{2} \mathrm{O}_{5}$ & 0,29 & & \\
\hline
\end{tabular}

Spektra IR dari zeolit termodifikasi ditizon. Terjadi pergeseran bilangan gelombang 3400-3700 $\mathrm{cm}^{-1}$ kearah yang lebih besar yaitu menjadi $3448,72 \mathrm{~cm}^{-1}$. Hal ini menunjukkan adanya gugus $-\mathrm{OH}$ dari zeolit berikatan dengan gugus $-\mathrm{NH}$ dari ditizon. Munculnya dua serapan baru pada bilangan gelombang 1496,76 dan $1435,04 \mathrm{~cm}^{-1}$ yang tampak pada zeolit setelahdimodifikasi ditizon, masingmasing merupakan interpretasi dari vibrasi tekuk $-\mathrm{NH}$ dan vibrasi ulur $-\mathrm{N}=\mathrm{N}-$. Terdapat juga pita serapan lemah yang muncul pada $2461,17 \mathrm{~cm}^{-1}$ menunjukkan adanya $-\mathrm{SH}$, sedangkan pita pada 2276,00 $\mathrm{cm}^{-1}$ menunjukkan adanyaC $=\mathrm{N}$.

Hasil ini memperkuat penelitian yang telah dilakukan sebelumnya tentang keberadaan gugus $-\mathrm{SH}$ dan $\mathrm{C}=\mathrm{N}$ pada kitin terimmobilisasi ditizon ${ }^{(19)}$. Serapan untuk regangan $-\mathrm{C}=\mathrm{S} \quad\left(1200-1050 \mathrm{~cm}^{-1}\right)$ dari molekul ditizon tidak muncul pada spektrum zeolit termodifikasi ditizon, karena pita serapan ini bergabung kedalam serapan dari Si-O-Si yang kuat di daerah $1018,41 \mathrm{~cm}^{-1(12)}$. Hasil analisis luas permukaan spesifik disajikan dalam Tabel 3.

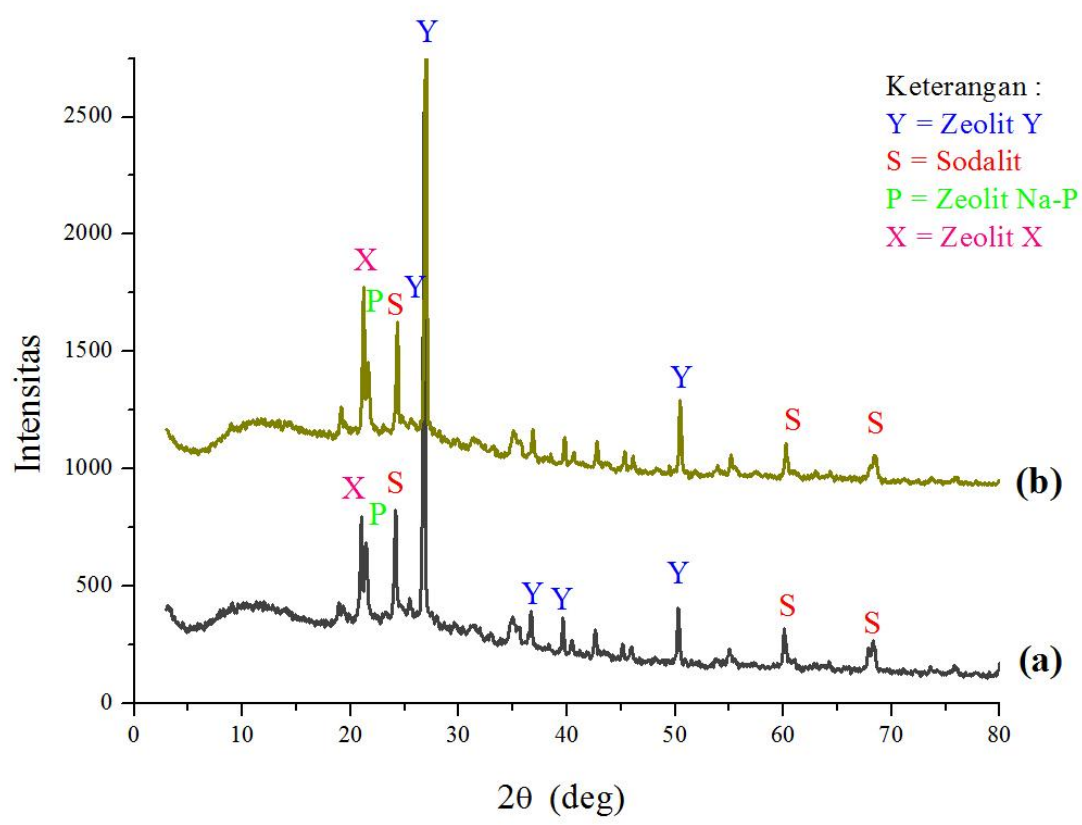

Gambar 1. Difraktogram: (a) Zeolit sintesis dan (b) Zeolit ditizon 


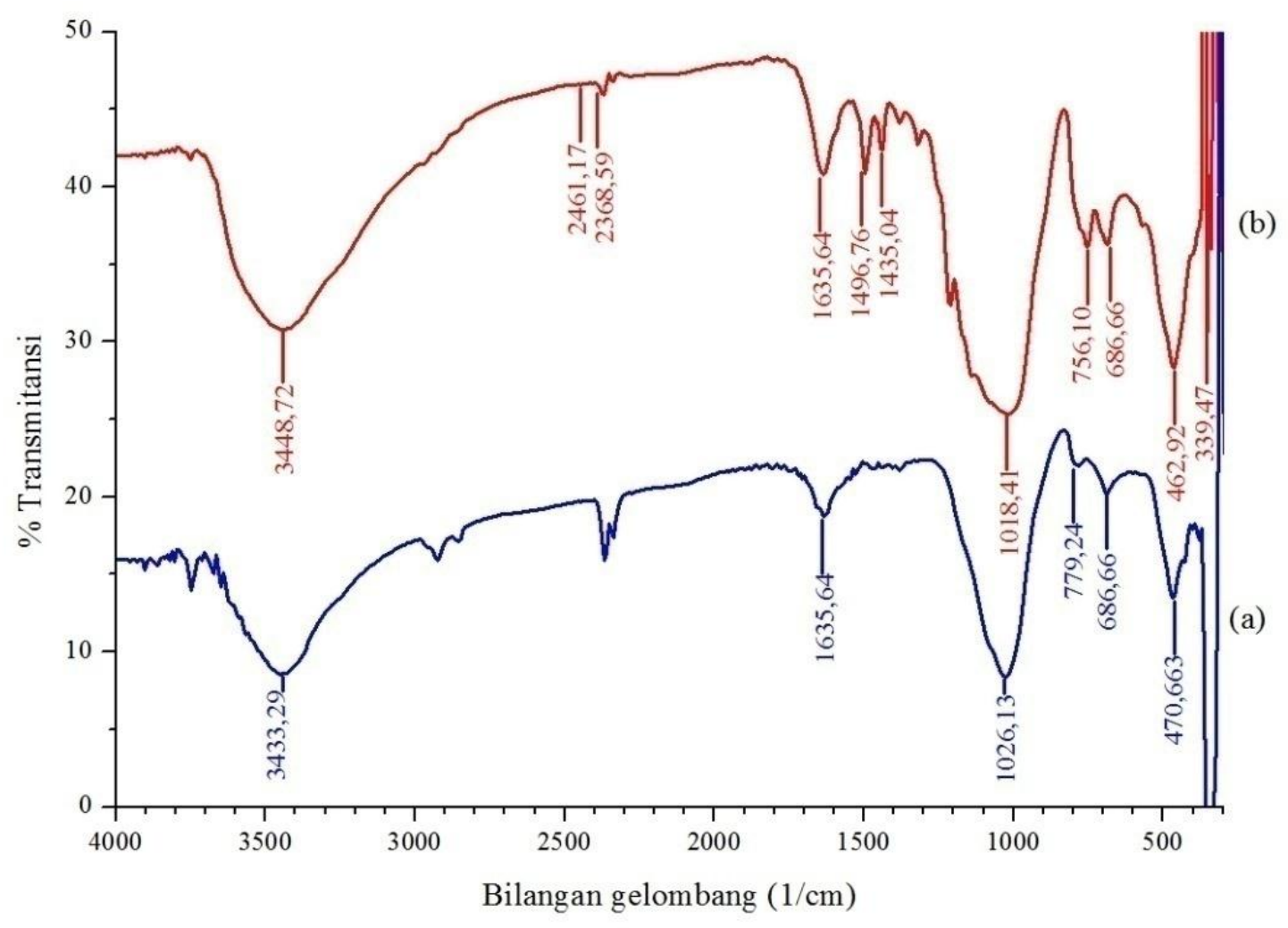

Gambar 2. Hasil FTIR: (a) Zeolit sintesis dan (b) Zeolit ditizon

Tabel 3. Data luas permukaan spesifik, volume total pori dan rerata jejari pori zeolit sintesis dan zeolit termodifikasi ditizon

\begin{tabular}{lccc}
\hline Jenis Sampel & $\begin{array}{c}\text { Luas permukaan } \\
\text { spesifik }\left(\mathbf{m}^{\mathbf{2}} \mathbf{g}\right)\end{array}$ & $\begin{array}{c}\text { Volume total pori } \\
(\mathbf{c c} / \mathbf{g})\end{array}$ & $\begin{array}{c}\text { Rerata jari pori } \\
(\AA \mathbf{A})\end{array}$ \\
\hline Zeolit sintesis & 160,262 & 0,2188 & 27,3065 \\
\hline Zeolit-ditizon & 69,609 & 0,1846 & 53,0304 \\
\hline
\end{tabular}

Berdasarkan Tabel 3 terlihat bahwa penambahan ditizon ke dalam zeolit sintesis menyebabkan penurunan luas permukaan spesifik dan volume total pori. Hal ini disebabkan karena senyawa ditizon yang diimobilisasi pada permukaan zeolit akan menutupi pori sehingga ukuran pori semakin kecil dan menghasilkan luas permukaan yang lebih kecil. Semakin banyak senyawa ditizon yang diimmobilisasikan maka semakin kecil luas permukaan spesifiknya. Hasil ini memperkuat penelitian yang telah dilakukan sebelumnya yang menunjukkan zeolit alam setelah diimmobilisasi dengan ditizon memberikan luas permukaan dan volume total pori yang lebih rendah ${ }^{(20)}$.

\section{Pengaruh pH terhadap adsorpsi Mn(II)}

Pengaruh $\mathrm{pH}$ terhadap proses adsorpsi ion logam $\mathrm{Mn}$ (II) menggunakan adsorben zeolit dan zeolit termodifikasi ditizon disajikan pada Gambar 3. 


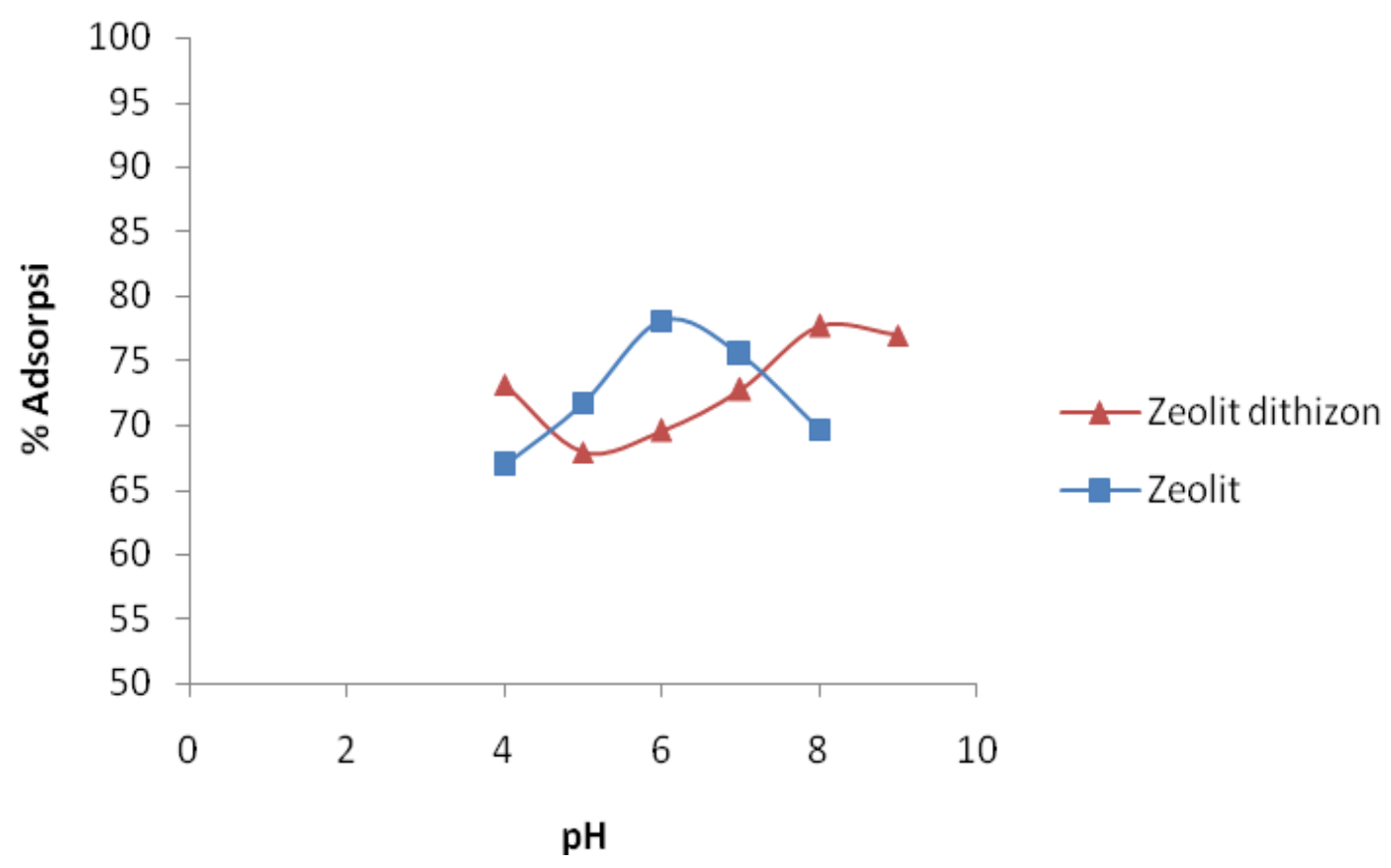

Gambar 3. Grafik pengaruh $\mathrm{pH}$ terhadap adsorpsi ion logam Mn(II)

Pengaruh $\mathrm{pH}$ adsorpsi zeolit termodifikasi ditizon terhadap ion $\mathrm{Mn}$ (II) lebih rendah dibandingkan dengan adsorben zeolit tanpa modifikasi. Hal ini dapat dijelaskan dengan konsep keasaman menurut pearson dalam diklasifikasikan menjadi asam basa keras dan lunak. Salah satu faktor yang mempengaruhi pembentukan kompleks logam-ligan adalah HSAB (Hard and Soft Acids and Bases), dimana asam merupakan akseptor pasangan elektron bebas (bermuatan positif) dan basa merupakan donor pasangan elektron bebas (beruatan negatif). Menurut konsep HSAB, asam keras akan berinteraksi/berikatan kuat dengan basa keras sedangkan asam lunak akan berinteraksi dengan basa lunak. Jika dihubungkan dengan konsep HSAB, ditizon mempunyai gugus aktif $-\mathrm{SH}$ dan $\mathrm{NH}$ yang termasuk dalam golongan basa lunak dan basa menengah. Gugus-gugus aktif ini secara selektif bereaksi membentuk kompleks dengan ion logam dalam golongan asam lunak dan menengah ${ }^{(21,22)}$. Sedangkan ion $\mathrm{Mn}^{2+}$ termasuk dalam golongan asam keras.Hal tersebut mengakibatkan interaksi antara ion $\mathrm{Mn}^{2+}$ dengan zeolit termodifikasi ditizon tidak lebih baik dan cenderung lemah.

\section{Kinetika adsorbsi Mn(II)}

Model yang digunakan adalah model kinetika Pseudo Orde 1 dan Pseudo Orde 2. Model persamaan kinetika adsorpsi pseudo orde pertama dan pseudo orde kedua dibuat dengan cara memplot antara $t$ vs $\ln$ (qe-qt) (Gambar 4) dan t vs t/qt (Gambar 5) sebagai persamaan Lagergen, sehingga dapat ditentukan nilai linearitas $\left(\mathrm{R}^{2}\right)$, konstanta laju adsorpsi (k), dan kapasitas adsorpsi (qe). Dapat teramati bahwa nilai konstanta laju adsorpsi secara signifikan lebih tinggi untuk zeolit termodifikasi ditizon sebesar 0,020 $\mathrm{g} / \mathrm{mg} \mathrm{min}^{-1}$ dibanding zeolit sebesar $-0,014$ g/mg. min $^{-1}$. Hal ini menunjukkan bahwa kemampuan interaksi antara zeolit termodifikasi ditizon lebih cepat dibandingkan dengan zeolit saja. 
JKTI, Vol. 17, No. 2, Desember 2015

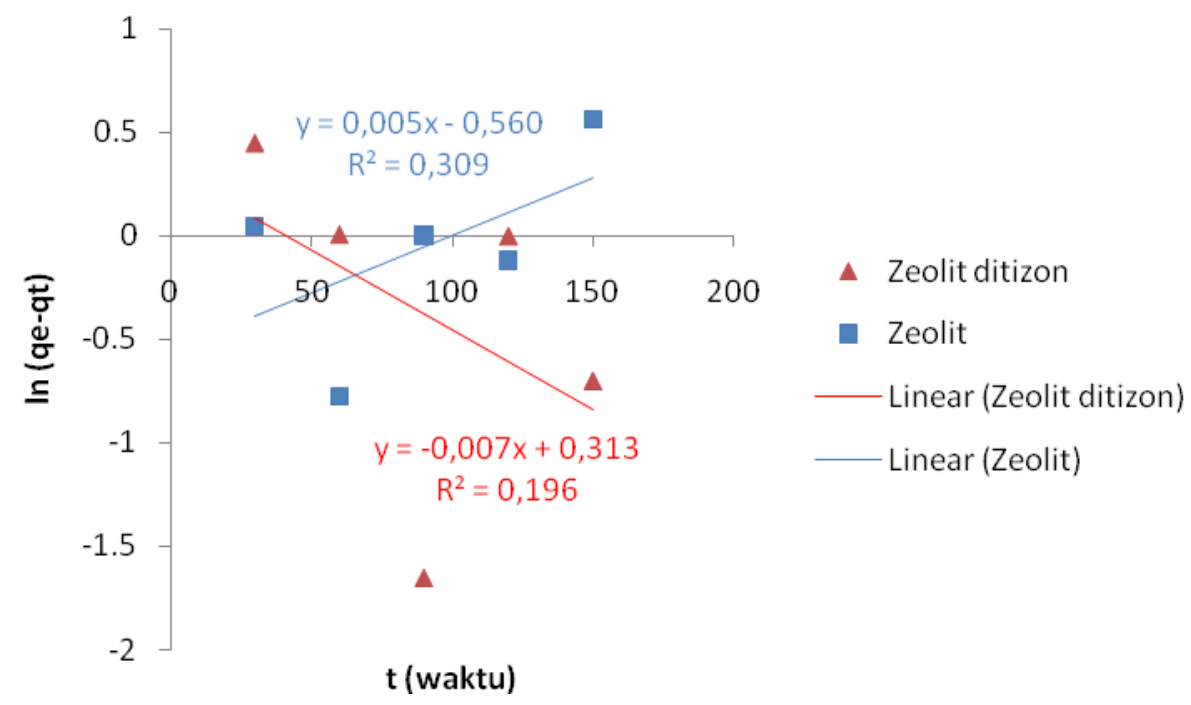

Gambar 4. Grafik pseudo orde pertama dari zeolit dan zeolit termodifikasi ditizon

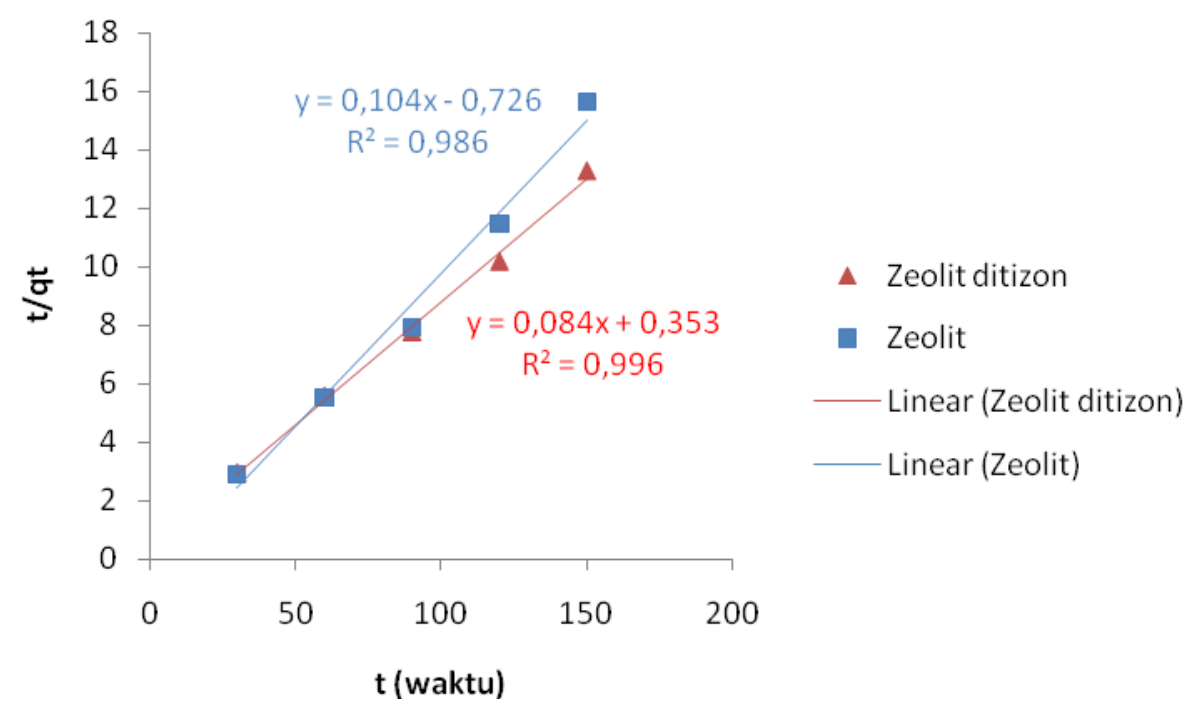

Gambar 5. Grafik pseudo orde kedua dari zeolit dan zeolit termodifikasi ditizon

Tabel 4. Model kinetika adsorpsi zeolit sintesis dan zeolit termodifikasi ditizon

\begin{tabular}{|c|c|c|c|}
\hline \multicolumn{2}{|c|}{ Model kinetika } & \multirow{2}{*}{\multicolumn{2}{|c|}{ Parameter }} \\
\hline \multicolumn{2}{|c|}{ Pseudo-orde pertama } & & \\
\hline Adsorben & $\mathrm{k}_{1}\left(\min ^{-1}\right)$ & qe $(\mathrm{mg} / \mathrm{g})$ & $\mathrm{R}^{2}$ \\
\hline Zeolit & 0,005 & 0,571 & 0,309 \\
\hline Zeolit-ditizon & 0,007 & 1,367 & 0,196 \\
\hline \multicolumn{2}{|c|}{ Pseudo-orde kedua } & \multicolumn{2}{|c|}{ Parameter } \\
\hline Adsorben & $\mathrm{k}_{2}\left(\mathrm{~g} / \mathrm{mg} \cdot \mathrm{min}^{-1}\right)$ & qe $(\mathrm{mg} / \mathrm{g})$ & $\mathrm{R}^{2}$ \\
\hline Zeolit & $-0,014$ & 9,615 & 0,986 \\
\hline Zeolit-ditizon & 0,020 & 11,904 & 0,996 \\
\hline
\end{tabular}




\section{Kesetimbangan adsorpsi Mn(II)}

Pada penelitian ini, digunakan dua model kesetimbangan adsorpsi yaitu model isoterm Langmuir dan isoterm Freundlich yang dapat dikaji untuk mengetahui model isoterm adsorpsi yang sesuai pada adsorpsi ion $\mathrm{Mn}(\mathrm{II})$ oleh zeolit dan zeolit
ditizon.Gambar 6 menujukkan hubungan antara $\mathrm{Ce}$ vs Ce/qe pada grafik isoterm Langmuir dari zeolit dan zeolit termodifikasi ditizon sedangkan Gambar 7 menunjukkan hubungan antara $\log \mathrm{Ce}$ vs log qe pada grafik isoterm Freundlich dari zeolit dan zeolit termodifikasi ditizon.

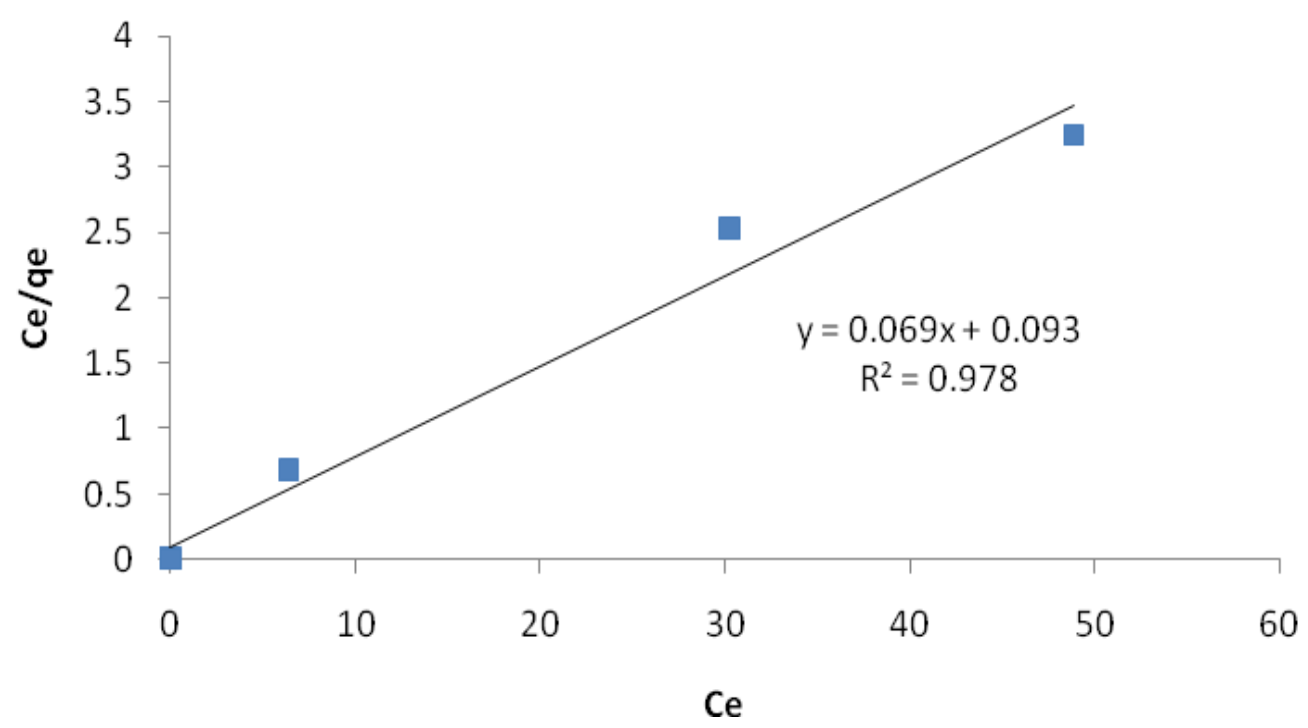

(a)

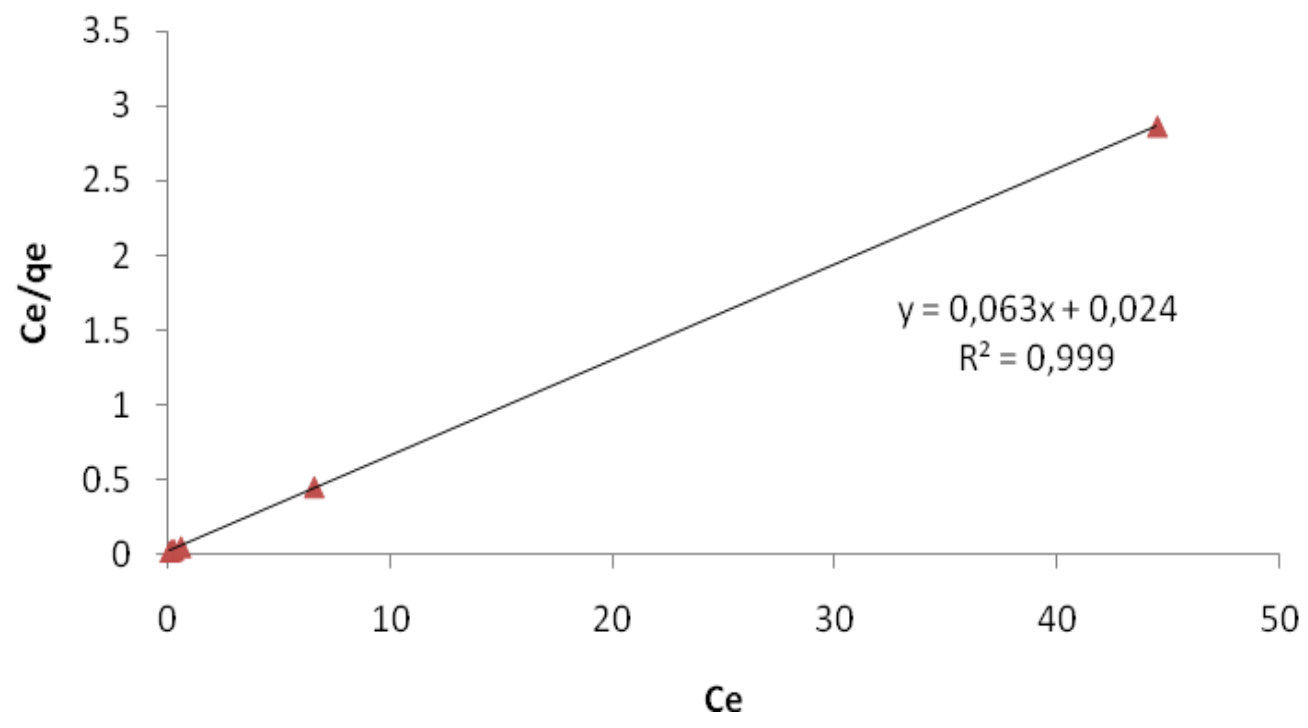

(b)

Gambar 8. Grafik isoterm Langmuir pada adsorben: (a) zeolit dan (b) zeolit termodifikasi ditizon 


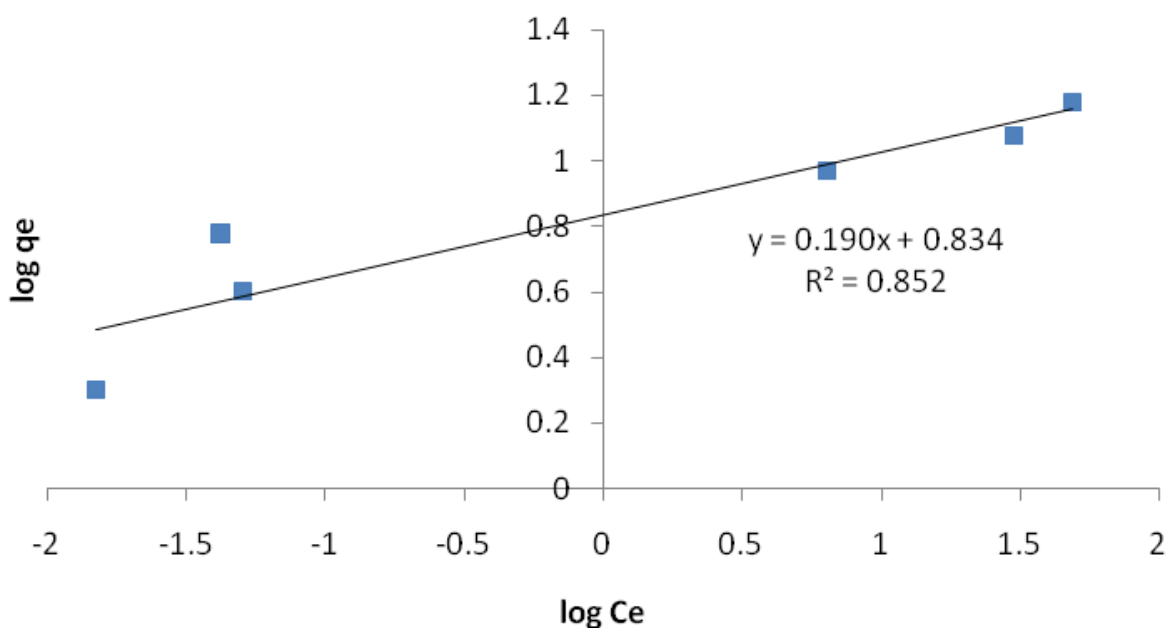

(a)

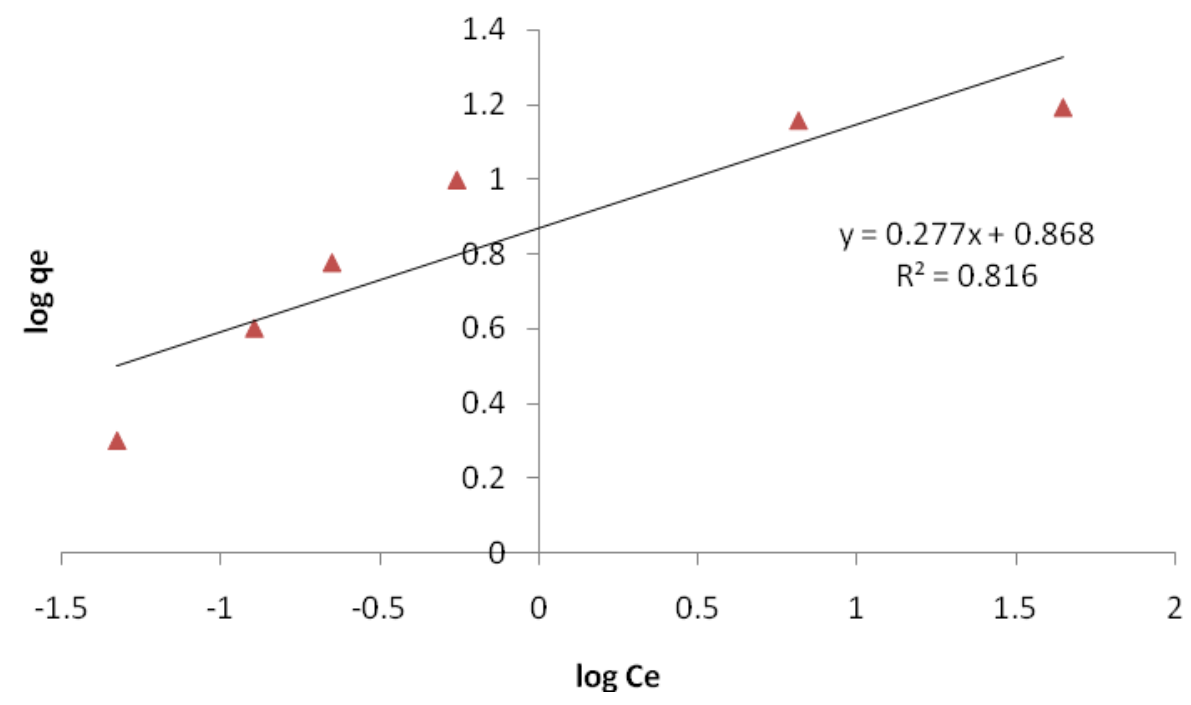

(b)

Gambar 7. Grafik isoterm Freundlich pada adsorben: (a) zeolit dan (b) zeolit termodifikasi ditizon

Tabel 5. Model isoterm adsorpsi zeolit sintesis dan zeolit termodifikasi ditizon

\begin{tabular}{|c|c|c|c|}
\hline \multicolumn{2}{|c|}{ Model isoterm adsorpsi } & \multirow{2}{*}{\multicolumn{2}{|c|}{ Parameter }} \\
\hline \multicolumn{2}{|c|}{ Langmuir } & & \\
\hline Adsorben & $\mathrm{K}_{\mathrm{L}}(\mathrm{mg} / \mathrm{L})$ & $q_{\max }(\mathrm{mg} / \mathrm{g})$ & $\mathbf{R}^{2}$ \\
\hline Zeolit sintesis & 0,742 & 14,493 & 0,978 \\
\hline Zeolit-ditizon & 2,625 & 15,873 & 0,999 \\
\hline \multicolumn{2}{|c|}{ Freundlich } & \multicolumn{2}{|c|}{ Parameter } \\
\hline Adsorben & $\overline{\mathbf{K}_{\mathrm{F}}}$ & $\mathbf{n}$ & $\mathbf{R}^{2}$ \\
\hline Zeolit sintesis & 6,823 & 5,263 & 0,852 \\
\hline Zeolit-ditizon & 7,380 & 3,610 & 0,816 \\
\hline
\end{tabular}


Berdasarkan Tabel 5 menunjukkan bahwa adsorpsi $\mathrm{Mn}(\mathrm{II})$ pada permukaan zeolit dan zeolit ditizon cenderung mengikuti persamaan Langmuir dimana adsorpsi yang terjadi bersifat monolayer dengan ikatan kimia (kemisorpsi). Adanya ditizon sedikit mempengaruhi kemampuan adsopsi yang ditunjukkan dengan peningkatan kapasitas adsorpsi maksimum $\left(\mathrm{q}_{\max }\right)$ zeolit sintesis sebesar $14,49 \mathrm{mg} / \mathrm{g}$ menjadi $15,87 \mathrm{mg} / \mathrm{g}$ pada zeolit termodifikasi ditizon.

\section{Termodinamika adsorpsi Mn(II)}

Pada parameter termodinamika terdapat hubungan antara konstanta kesetimbangan adsorpsi dengan suhu yang dapat menentukan perubahan energi bebas Gibbs $\left(\Delta \mathrm{G}^{\mathrm{o}}\right)$, entalpi $\left(\Delta \mathrm{H}^{\mathrm{o}}\right)$ dan entropi $\left(\Delta S^{\circ}\right)$. Proses adsorpsi dapat diprediksi melalui hubungan antara konstanta kesetimbangan adsorpsi ( $\left.\mathrm{K}_{\mathrm{ads}}\right)$ dengan suhu. Grafik hubungan antara ln Kads dengan 1/T dapat dilihat pada Gambar 8.

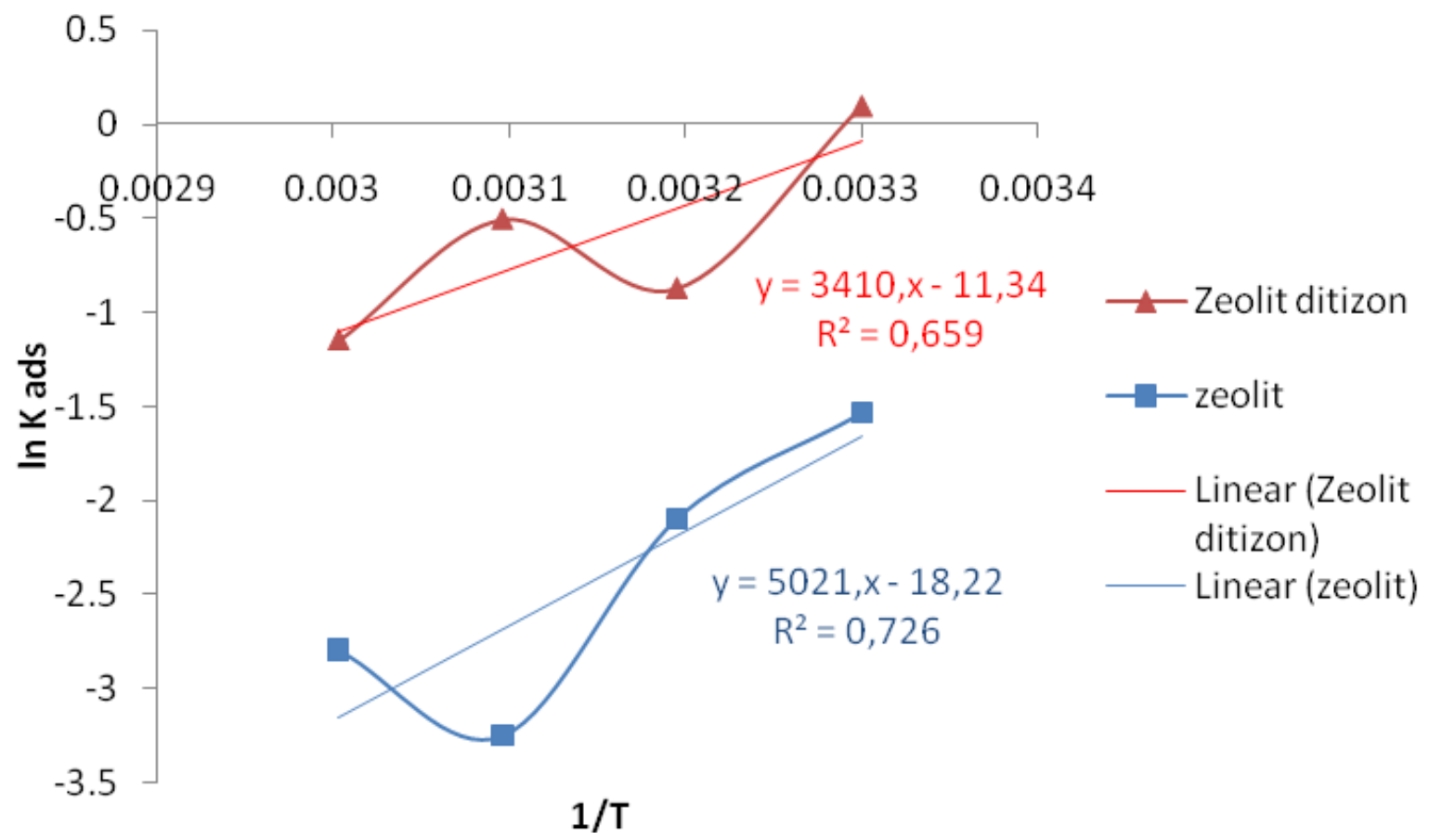

Gambar 8. Grafik termodinamika adsorpsi ion logam Mn(II) pada adsorben zeolit dan zeolit termodifikasi ditizon

Tabel 6. Parameter termodinamika adsorpsi ion logam $\mathrm{Mn}(\mathrm{II})$

\begin{tabular}{ccccc}
\hline Sampel & $\begin{array}{c}\mathbf{T} \\
(\mathbf{K})\end{array}$ & $\begin{array}{c}\Delta \mathbf{S}^{\mathbf{0}} \\
(\mathbf{k J . K} / \mathbf{m o l})\end{array}$ & $\begin{array}{c}\Delta \mathbf{H}^{\mathbf{0}} \\
(\mathbf{k J} / \mathbf{m o l})\end{array}$ & $\begin{array}{c}\Delta \mathbf{G}^{\mathbf{0}} \\
(\mathbf{k J} \mathbf{m} \mathbf{m o l})\end{array}$ \\
\hline \multirow{3}{*}{ Zeolit sintesis } & 303 & $-0,15$ & $-41,74$ & 4,15 \\
& 313 & & & 5,66 \\
& 323 & & & 7,18 \\
\hline Zeolit & 333 & $-0,094$ & $-28,35$ & 8,69 \\
termodifikasi & 303 & & & 0,21 \\
ditizon & 323 & & & 1,15 \\
& 333 & & & 3,10 \\
\hline
\end{tabular}


Berdasarkan Tabel 6 kedua adsorben mempunyai nilai $\Delta \mathrm{G}^{\mathrm{o}}$ positif, yang menunjukkan bahwa reaksi berjalan tidak spontan. Namun, karena nilai $\Delta \mathrm{S}^{\mathrm{o}}$ negatif, dapat dikatakan adsopsi menggunakan kedua adsorben ini berlangsung spontan pada suhu yang lebih rendah. Dari data tersebut terjadi penurunan derajat ketidakteraturan pada sistem adsorbenadsorbat, jadi ion-ion logam yang terjerap pada adsorben semakin teratur.

\section{KESIMPULAN}

Sintesis zeolit dari abu dasar batubara dengan metode peleburan hidrotermal telah berhasil dilakukan dan didapatkan material yaitu zeolit $\mathrm{Y}$, sodalit, zeolit Na-P dan zeolit $X$. Zeolit termodifikasi ditizon berhasil disintesis dengan ditunjukkannya gugus $-\mathrm{NH}$ dan SH pada bilangan gelombang 1496,76 dan $2461,17 \mathrm{~cm}^{-1}$ pada analisa FTIR. Hasil GSA menunjukkan penambahan ditizon pada zeolit menurunkan luas permukaan spesifik dari $160,262 \mathrm{~m}^{2} / \mathrm{g}$ menjadi $69,609 \mathrm{~m}^{2} / \mathrm{g}$. Berdasarkan model kinetika, zeolit sintesis dan zeolit termodifikasi ditizon mengikuti model kinetika pseudo orde kedua, sedangkan isoterm adsorpsi mengikuti model Langmuir. Nilai kapasitas adsorpsi maksimum zeolit sintesis adalah 14,493 $\mathrm{mg} / \mathrm{g}$ dan zeolit termodifikasi ditizon sebesar 15,873 mg/g. Model termodinamika adsorpsi ion logam Mn(II) oleh zeolit sintesis dan zeolit termodifikasi ditizon menunjukkan adsorpsi berlangsung spontan pada temperatur rendah.

\section{UCAPAN TERIMAKASIH}

Penulis mengucapkan terima kasih kepada Program studi Kimia UIN Sunan kalijaga Yogyakarta karena penelitian ini merupakan bagian dari skripsi pada program studi tersebut dan telah dipresentasikan dalam Seminar Nasional Teknik Kimia "Kejuangan'", dengan tema Pengembangan Teknologi Kimia untuk Pengolahan Sumber Daya Alam Indonesia, di Yogyakarta, 18 Maret 2015. Artikel ini ditulis ulang dari proseding seminar tersebut dengan beberapa perubahan.

\section{DAFTAR PUSTAKA}

1. R.K. Hessley, J.W Reasoner dan J.T Riley. Coal Science, An Introduction to Chemistry, Technology and Utilization. Mc Graw Hill Publishing Company Limited: London 1986

2. H. Hamdan. Introduction to Zeolites: Synthesis, Characterization, and Modification. Universiti Malaysia, Malaysia, 1992.

3. Y. Yanti. Sintesis zeolit A dan Zeolit Karbon Aktif dari Abu Dasar PLTU Paiton dengan Metode Peleburan. Institut Teknologi Sepuluh Nopember: Surabaya. 2009.

4. H. Atminingsih, Sintesis Zeolit dari Abu Dasar Batubara dengan Metode Hidrotermal Langsung. Tesis. Institut Teknologi Sepuluh Nopember: Surabaya. (2009)

5. H.L Chang. dan W.H Shih. Synthesis of Zeolites A and X from Fly Ashes and Their Ion-Exchange Behavior with Cobalt Ions.Industrial Engineering Chemistry Res., vol. 39. hal. 41854191. (2000)

6. S. Wang danY. Peng, Natural Zeolites as Effective Adsorbents in Water and Wastewater Treatment. Chem. Eng. 156. 11-24. (2010).

7. H. Kurama, A. Zimmer, dan $\mathrm{T}$ Reschetilowski. Chemical Modification Effect on the Sorption Capacities of Natural Clinoptilolite. Chem. Eng. Technology. 25. 301-305. (2002) 
8. Z. Marczenko. Separation and Spetrophotomettric Determination of Elemens. Ellis Horwood Limited: England. 1986.

9. Mudasir, D. Siswanta. Adsorption Characteristics of $\mathrm{Pb}(\mathrm{II})$ and $\mathrm{Cd}(\mathrm{II})$ Ions on Dithizone loaded Natural Zeolite. J Ion Exchange. Vol.18 No.4. (2007)

10. M.E. Mahmoud, M.M Osman, O.F. Hafez, A.H. Hegazi dan E. Elmelegy, Removal and preconcentration of lead(II) and other heavy metals from water by alumina adsorbents developed by surfaceadsorbed - dithizone. Desalination. 251: 123-130 (2010).

11. B.R. Putra, Tugas Akhir S-1, Fakultas Matematika dan Ilmu Pengetahuan Alam, Institut Pertanian Bogor. 2010.

12. H.M. Yu, H. Song, M.L. Chena, Dithizone immobilized silica gel online preconcentration of trace copper with detection by flame atomic absorption spectrometry. Talanta 85: 625-630 (2011).

13. M. Anaraki, N. Alireza, Modification of clinoptilolite nanoparticels by a cationic surfactant and dithhizone for removal of $\mathrm{Pb}$ (II) from aqueous solution. J Collid Interface Sci. 440: 1310 (2014)

14. W.Trisunaryanti, Kimia Zat Padat. Buku Ajar Pascasarjana FMIPA UGM: Yogyakarta. 2006.

15. Y.J. Hwang, et al. Photoactivity of CdS Particles Grown in Pt loaded Zeolite Y. Bull. Korean Chem. Soc. Vol. 21, No. 2. Korea: Department of Chemistry, Ewha Womans University, 2000.

16. X. Querol, N. Moreno, JC. Umana, A. Alastuey, E. Hernandez, A. Lopez Soler, F. Plana. Synthesis of Zeolites from Fly Ash: an overview. International Journal Coal Geol. 50: 413-423 (2002).
17. M.Z. Muhlisin. Tugas Akhir S-1. FMIPA UNNES Semarang. 2008.

18. Sutarno, Y. Arryanto dan A. Budhyantoro, Sintesis Faujasite dari Abu Layang Batubara: Pengaruh Refluks dan Penggerusan Abu Layang Batubara terhadap Kristalinitas Faujasite. Jurnal Matematika dan Sains Vol. 9 No. 3. hal. 285-290. (2004)

19. Mudasir, G. Raharjo, I. Tahir. E. Wahyuni, Immobilization of Dithizone onto Chitin Isolated from Prawn Seawater Shells( $P$. merguensis) and its Preliminary Study for the Adsorption of Cd(II) Ion. Journal of Physical Science, Vol. 19(1), 63-78 (2008).

20. A. Suseno, Immobilisasi Dithizon Secara Fisika pada Zeolit Alam dan Studi Kemampuan Adsorpsinya terhadap Logam $\mathrm{Pb}(\mathrm{II})$. Jurnal Kimia dan Teknologi. ISSN 0216 - 163 X. (2010).

21. K. Ojha, Y. Sig dan S.A. Wha, Zeolit From Fly Ash: Synthesis and Characterization, Bull, Mater. Indian Academy of Sciences, 27, 555-564. (2004).

22. W. Prodinger, Organic Reagents Used in Quantitative Analysis, Elsevier Publishing Company Inc., New York. 1940. 
JKTI, Vol. 17, No. 2, Desember 2015 